\title{
Food Sovereignty as an Alternative to Reduce the Serious Hunger Problem or Food Shortage Worldwide
}

\author{
Ortega-Ibarra E*, Ortega-Ibarra IH, Díaz-Santiago HD, Luna-Hernández JF, \\ Ramírez Díaz MP, Hernández Ramírez G and Marín-Velázquez J
}

Universidad del Istmo Campus Juchitán (Universidad del Istmo), México

*Corresponding author: Edú Ortega Ibarra. Universidad del Istmo (UNISTMO), Carretera Transístmica Juchitán- La Ventosa Km 14 S/N, La Ventosa, Oaxaca, Mexico. Zip Code: 70102 Tel: 2281388032 e-mail: eoi@bizendaa.unistmo.edu.mx

\section{Perspective \\ Volume 4 Issue 2}

Received Date: February 26, 2021

Published Date: March 17, 2021

DOI: $10.23880 /$ jqhe-16000209

\section{Abstract}

In 1996 Via Campesina launched an initiative claiming that peoples had the right to affordable, nutritious and culturally appropriate food produced using sustainable and ecological processes, as well as the right to define their own management policies related to agriculture, water, fisheries, land, seeds and biodiversity. This initiative, which constitutes a broad framework for the enforcement of the right to food, has emerged as a response and an alternative to the neoliberal model fostering corporate globalization. Also, it is global and provides a framework to understand and transform governance. This concept -consisting of six well-defined pillars (focuses on food for people, values food providers, localizes food systems, puts control locally, develops knowledge and skills, work with nature) can help avoid food poverty, since it aims to guarantee access to healthy and sufficient nutrition for all people, especially the most vulnerable sectors, such as children, pregnant women and older adults, who hardly achieve a proper living. The World Forum on Food Sovereignty, shares objectives and actions to also help through seven areas: trade policies and local markets, knowledge and local technology, access to and control over natural resources, the exchange of territories in all sectors, response to conflicts and natural disasters, migration and production models.

Keywords: Food; Food Sovereignty; Right to Food; Food Security; Agriculture

\section{Introduction}

Nowadays, hunger and malnutrition are not owing to a shortage or lack of food, but food access, low income or productive resources that allow poor people to produce or buy enough food. Unequal distribution of food, land and other productive resources is the main cause of hunger and malnutrition [1]. Therefore, food is a basic need and access to food is essential for human survival [2]. Despite the fact that we are in the $21^{\text {st }}$ century, there have been struggles to solve the hunger problem and to date official figures estimate that 800 million people are still hungry [3]. Half of the hungry people are small-scale producers who live on a limited land area without adequate access to productive resources, while two thirds of them live on marginal lands under environmentally difficult conditions. However, secured access to productive resources is key to improving the situation of many families [1].

\section{Origin of Food Sovereignty}

The Food Sovereignty (FS) concept was developed by people who are the most threatened by the consolidation of power in the food and agricultural systems, i.e. peasant farmers. This concept consists of a systematic change in which human beings have a direct and democratic control of the most important elements of their society, that is, what we eat, how we use and maintain the land, water and other resources in our environment for the benefit of current and future generations, as well as how we interact with other 
groups, people and cultures.

Via Campesina launched the FS concept in 1996 at the Civil Society Forum held in Rome, which organized an independent international planning committee, the World Summit on Food. In this forum a set of requirements, which offered an alternative to world trade policies and made the human right to food a reality, was presented. In the declaration "Food Sovereignty: a future with no hunger" Via Campesina claimed that "FS is a precondition for genuine food security" and, therefore, the right to food can be seen as a mechanism to achieve this. 1 However, there was no formal definition, so Via Campesina held two international conferences to explain this concept: The World Forum on Food Sovereignty, which made clear the objectives and actions of this movement and dealt with seven areas (1. Trade policies and local markets; 2. Knowledge and local technology; 3. Access to and control over natural resources; 4. The exchange of territories in all sectors; 5 . Response to conflicts and natural disasters; 6. Migration and 7. Production models); and the World Forum for Food Sovereignty, where FS was stated to be an alternative to the neoliberal policies implemented in developing countries $[4,5]$.

Priority of food production for national markets, fair prices and protecting internal markets against external subsidized products, access to land, water and other resources for production, trade, support for investment in productive activities and community development are the main elements associated with FS [5].

Therefore, the FS concept is understood as the capacity and right that peoples and nations have to determine, according to their own interests, historical and socio-cultural preferences, the type of agricultural products that will serve as a basis for feeding their population, assuming that it is a high priority for them to promote a development model in order to strengthen the internal market and incorporate rural areas to achieve sustainable development [5]. Thus, it is a response and an alternative to the neoliberal model fostering corporate globalization. Also, FS is global and provides a policy framework to understand and transform the international governance of food and agriculture, meaning solidarity, not competition. Moreover, FS aims to build a fairer world with a bottom-up approach [2].

\section{Pillars of Food Sovereignty}

As mentioned above, Via Campesina organized a World Forum for Food Sovereignty that aimed to strengthen the movement, expand capacities for action and solidarity, learn from the experiences of others, think strategically about international and local struggles, as well as favor diversity of people, places and cultures represented by Via Campesina.
As an outcome of this forum, the 2007 Nyéléni Declaration for Food Sovereignty was created and pillars of FS were identified [2-6].

1. Focuses on food for people: FS puts people, including those who suffer from hunger and live in occupied, struggling and marginalized zones, at the center of food, agriculture, livestock and fisheries policies by ensuring sufficient, nutritious and culturally appropriate food for all individuals, peoples and communities while rejecting the proposal that food is just another commodity or a component of international agribusiness.

2. Values food providers: FS values and supports the contributions, and respects the rights, of women and men, peasants and small scale family farmers, pastoralists, artisanal fisherfolk, forest dwellers, indigenous peoples and agricultural and fisheries workers, including migrants, who cultivate, grow, harvest and process food; and rejects those policies, actions and programs that undervalue them, threaten their livelihoods and eliminate them.

3. Localizes food systems: FS brings food providers and consumers closer together; puts providers and consumers at the center of decision-making on food issues; protects food providers from the dumping of food and food aid in local markets; protects consumers from poor quality and unhealthy food, inappropriate food aid and food tainted with genetically modified organisms; and resists governance structures, agreements and practices that depend on and promote unsustainable and inequitable international trade and give power to remote and unaccountable corporations.

4. Puts control locally: FS places control over territory, land, grazing, water, seeds, livestock and fish populations on local food providers and respects their rights. They can use and share them in socially and environmentally sustainable ways which conserve diversity; it recognizes that local territories often cross geopolitical borders and ensures the right of local communities to inhabit and use their territories; it promotes positive interaction between food providers in different regions and territories and from different sectors that helps resolve internal conflicts or conflicts with local and national authorities; and rejects the privatization of natural resources through laws, commercial contracts and intellectual property rights regimes.

5. Develops knowledge and skills: FS builds on the skills and local knowledge of food providers and their local organizations that conserve, develop and manage localized food production and harvesting systems, developing appropriate research systems to support this and passing on this wisdom to future generations; and rejects technologies that undermine, threaten or contaminate these. 
6. Works with Nature: FS uses the contributions of nature in diverse, low external input agroecological production and harvesting methods that maximize the contribution of ecosystems and improve resilience and adaptation, especially in the face of climate change; it seeks to heal the planet so that the planet may heal us; and, rejects methods that harm beneficial ecosystem functions, that depend on energy intensive monocultures and livestock factories, destructive fishing practices and other industrialized production methods, which damage the environment and contribute to global warming.

Currently, Food Secure Canada claims there is a seventh pillar: food is sacred, added by members of the Indigenous Circle during the People's Food Policy process. This pillar recognizes that food is a gift of life and points out that food cannot be commodified nor squandered. ${ }^{7}$ The pillars of FS are essential, because this concept includes not only production and consumption of food, but also how the land is worked and how resources are used sustainably, that is, not only the quantities of food and its quality, but also from whom, where they are produced and how people access to them [7].

\section{Feeding and Food Sovereignity}

Feeding is one of the most urgent needs of people. Therefore, it is essential that governments guarantee their inhabitants their right to food [8]. This was established for the first time by the Universal Declaration of Human Rights in 1948, Rindermann RS, et al. [6] which introduced a different concept from that of food security or food sovereignty. The right to appropriate food is described as "the right of every man, woman and child alone and in community with others to have physical and economic access at all times to adequate food or means for its procurement in ways consistent with human dignity", implying that an individual can demand the government and communities to respect, protect and guarantee his or her needs for adequate access to sufficient food in an acceptable quantity [1,2].

It is also understood as the right to have regular, permanent and unrestricted access, either directly or by means of financial purchases, to quantitatively and qualitatively adequate and sufficient food corresponding to the cultural traditions of the people to which the consumer belongs, and which ensure a physical and mental, individual and collective, fulfilling and dignified life free of fear [8]. However, economic crises have increased price of food, affecting the right to food. Currently, there are around 800 million of hungry peopling worldwide and the majority is located in the sub-Saharan region, Central and Southeast Asia $[3,4]$. Nonetheless, agricultural production worldwide has tripled in less than a century, while the global population has also tripled. More importantly, according to the FAO World Food Report, world agriculture with its current production force could feed 12,000 million of human beings, considering that each adult would consume 2,700 calories per day. Unfortunately, the cause of hunger in this world is because of a radically unequal distribution of these assets, a very great injustice as $20 \%$ of the population owns $80 \%$ of these resources [4-9].

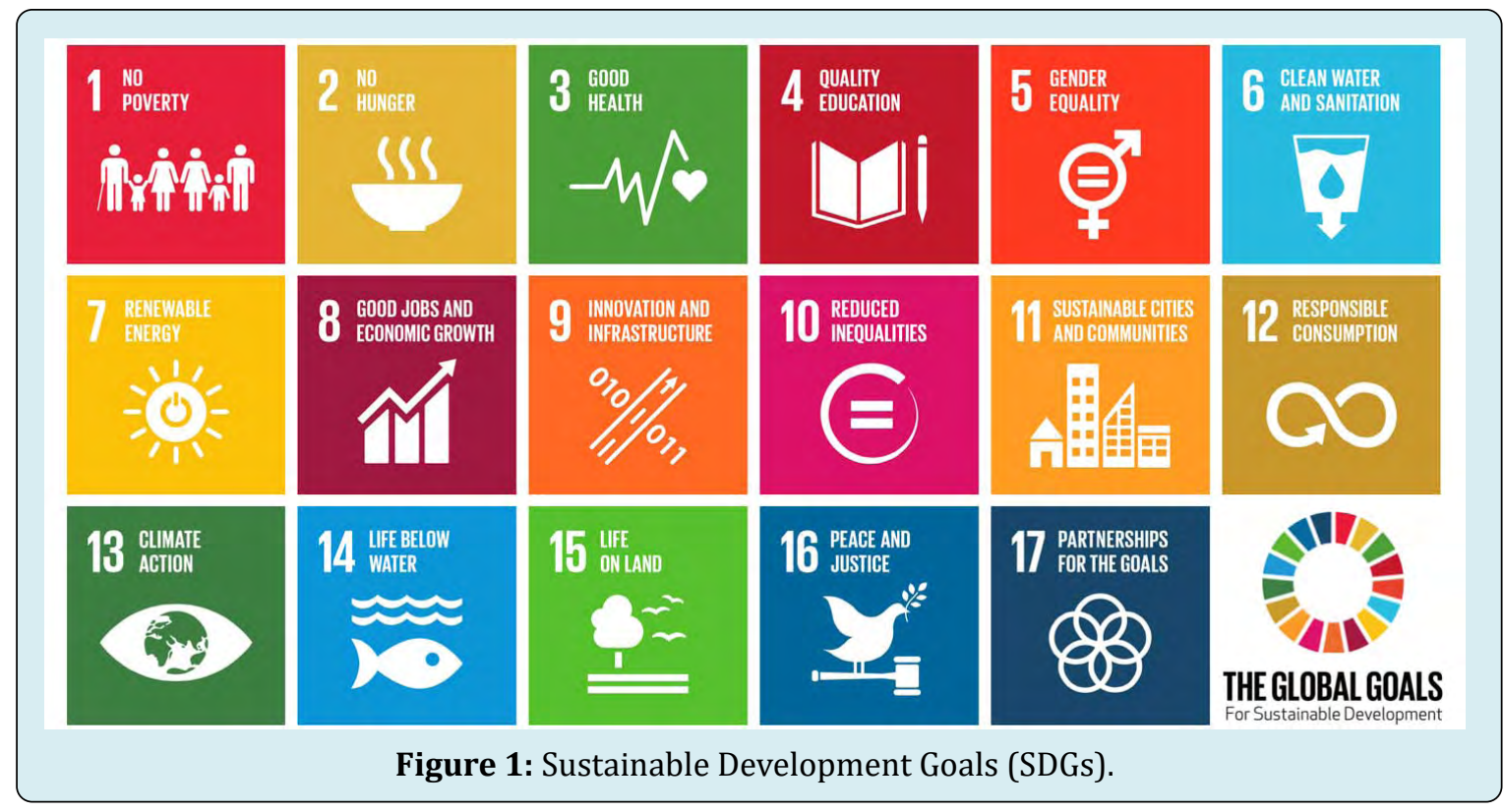

Therefore, after further failures to achieve progress and sustainable development, in the year 2000 the United
Nations held the Millennium Summit where the Millennium Development Goals (MDG's) emerged, and within these the 
Millennium Goals, which are strategies to expand health, eradicate poverty and fulfill fundamental human rights [10]. According to the United Nations, achieving most of the objectives is likely to occur. However, in 2015 monitoring MDG's was concluded, so 73 countries out of 129 were known to have achieved goal number one: eradicating poverty and hunger [4]. In 2016 the Sustainable Development Goals (SDG's) were launched (Figure 1), which were based on the MDG's, whose purpose is a universal call for adopting measures to end poverty, protect the planet and guarantee all people enjoy peace and prosperity [11].

\section{Conclusion}

All people have the right to receive appropriate food, including both the agricultural and livestock sectors, since they provide all the populations and communities of the world with food. Thus, the creation of food sovereignty considers that these sectors, including fisheries and other businesses, have the possibility to make their own policies or rights based on their own criteria and sectors that work, guaranteeing that these groups have access to appropriate and healthy food. Moreover, the population with no proper access to food also benefits.

Food sovereignty has fundamental pillars that may be related to reducing the big global food problem or food shortages. However, both MDGs and the SDGs are also essential, since they set goals that must be considered by policy-makers. Policy-makers should take the initiative to resolve this problem, because of these programs a percentage of the countries that implemented these programs were able to reduce their economic and food poverty. Thus, agriculture, livestock, and fishing should still be considered as essential to secure access to food for everyone, as well as keeping the economy of the countries ranking the first places in food poverty. Implementing a good food sovereignty policy, considering its pillars, could help the entire world population to benefit from the right to food, since it is not a matter of what country is richer, but what country offers a better quality for their habitants [12].

\section{Conflict of Interest}

The authors have no conflicts of interest to declare. All co-authors have seen and agreed with the contents of the manuscript and there is no financial interest to report.

\section{Acknowledgement}

Authors would like to thank Miguel de la Ferrelle Ortiz for writing and proofreading the English version of our manuscript.

\section{References}

1. Jonsen MWYJ (2005) Soberanía Alimentaria. Hacia la democracia en sistemas alimentarios locales.

2. ECVC (2018) Soberanía Alimentaria Ya! Una Guía por la Soberanía Alimentaria.

3. Perez JF, Ortiz BPV, Soto MLQ (2012) ¿Soberanía, seguridad, autosuficiencia o crisis alimentaria? Caso de México y la Región este de África. Problema básico en salud y calidad de vida. Rev Digit Univ 13(8): 1-19.

4. Maffra L (2017) Food Sovereignty: sustainable solution to world hunger and climate change. Ámbitos, Rev Int Comun (37): 1-11.

5. Lee R (2007) Food Security and Food Sovereignty.

6. Rindermann RS, Garay AVG (2014) Seguridad y Soberanía Alimentaria en México, Análisis y propuestas de política.

7. Gordillo G, Jeronimo OM (2013) Seguridad y Soberanía Alimentaria, (Documento base para discusión).

8. FSC (2018) What is Food Sovereignty?. Canadá: FSC.

9. Curiel AA, Sanchez JF, Rangel Faz G (2011) La política alimentaria en México. México CEDRSSA.

10. Ausin T (2010) El derecho a comer: los alimentos como bien público global. ARBOR Cien, Pens Cult (745): 847858.

11. Gonzalez DG, Solis MP, Cantero MTR, Moncada MDRO, Giraldo AF, et al. (2006) El reto para la salud pública de los Objetivos de Desarrollo del Milenio: un enfoque desde la epidemiología política. Gac Sanit 20(S3): 61-65.

12. PNUD (2019) Objetivos de Desarrollo Sostenible. 